$\begin{array}{ll}\text { Volume } & : 04 \\ \text { Nomor } & : 02 \\ \text { Bulan } & : \text { Mei } \\ \text { Tahun } & : 2018 \\ \text { http } & : \text { //ejurnal.pps.ung.ac.id/index.php/AKSARA/index }\end{array}$

\title{
Meningkatkan Hasil Belajar IPA Melalui Metode Pembelajaran Pratikum
}

\author{
Asia Yusuf \\ Guru Mata Pelajaran IPA SMP Negeri I Randangan \\ asiayusuf@gmail.com
}

\begin{abstract}
Abstrak:
Penelitian ini bertujuan untuk mengetahui peningkatan hasil belajar siswa kelas VII A SMP Negeri 1 Randangan pada mata pelajaran IPA melalui penerapan metode pembelajaran partikum. Subjek dalam penelitian ini adalah siswa kelas VII A SMP Negeri 1 Randangan yang berjumlah siswanya 27 orang, terdiri dari 15 siswa lakilaki dan 12 siswa perempuan. Penelitian ini dilakukan dengan menggunakan prosedur penelitian tindakan kelas (PTK). Prosedur penelitian ini terdiri dari dua siklus, dimana tiap siklus melalui 4 tahap yaitu : 1). Perencanaan, 2). Pelaksanaan, 3). Observasi, dan 4). Refleksi. Analisis data yang digunakan secara umum terdiri dari proses analisis untuk menghitung presentasi keaktifan siswa dan mengetahui tingkat hasil belajar siswa. Berdasarkan data dari siklus I dan II dapat dikatakan bahwa pembelajaran IPA melalui penerapan metode praktikum dapat meningkatkan keaktifan dan hasil belajar IPA. Terbukti pada siklus I keaktifan siswa mencapai $72,07 \%$ dan hasil belajar mencapai $64,07 \%$. Dengan perbaikan pembelajaran pada siklus II keaktifan siswa meningkat menjadi $83,95 \%$ dan hasil belajar mengalami peningkatan menjadi 77,03\%. Terbukti bahwa dengan penerapan metode praktikum IPA maka kwalitas pelaksanaan pembelajaran meningkat. Hal ini berarti hipotesis tindakan dalam penelitian ini dapat diterima
\end{abstract}

Kata Kunci: Hasil Belajar, metode pembelajaran praktikum

\section{Pendahuluan}

Mata pelajaran fisika di SMP adalah bagian dari mata pelajaran IPA yang mempelajari sifat materi, gerak, dan fenomena lain yang ada hubungannya dengan energi. Selain itu juga keterkaitan konsep- konsep fisika dengan kehidupan nyata dan kesadaran terhadap perkembangan ilmu pengetahuan antara lain adalah menggunakan ketrampilan proses untuk memperoleh, mengembangkan, dan menerapkan konsep- konsep fisika.

Perpindahan kalor merupakan salah satu materi yang terdapat pada mata pelajaran fisika, khususnya pada kelas VII disemester genap. Pada materi ini, siswa dituntut untuk dapat menerapkan konsep kalor dan prinsip konservasi energi pada berbagai perubahan energi dalam kehidupan sehari-hari. Jika ingin memperoleh hasil belajar perpindahan kalor yang baik, maka hendaknya guru membimbing siswa untuk memenuhi tuntutan tersebut. Akan tetapi kegiatan tersebut tidak berhasil pada pembelajaran perpindahan kalor kelas VII SMP Negeri 1 Randangan tahun pelajaran 2016/2017, dimana sebesar 64\% dari 30 siswa memperoleh nilai ulangan harian perpindahan kalor di bawah nilai KKM yang ditentukan oleh sekolah yaitu 68. Dari hasil ulangan harian, dapat diidentifikasi bahwa kesulitan siswa yaitu: (1) siswa belum bisa mendefinisikan tentang perpindahan kalor, (2) siswa belum bisa mendefinisikan tentang perpindahan kalor secara konduksi, 


$\begin{array}{ll}\text { Volume } & : 04 \\ \text { Nomor } & : 02 \\ \text { Bulan } & : \text { Mei } \\ \text { Tahun } & : 2018 \\ \text { http } & : / / \text { jurnal.pps.ung.ac.id/index.php/AKSARA/index }\end{array}$

konveksi, dan radiasi dengan baik dan benar, (3) sebagian besar siswa masih keliru dalam membedakan perpindahan kalor secara konduksi dan konveksi, (4) siswa tidak dapat menyebutkan satuan yang terdapat dalam materi perpinahan kalor. Dari kesulitan belajar siswa tersebut dapat diketahui bahwa pemahaman konsep yang kurang menyebabkan siswa mengalami kesulitan dalam menyelesaikan soal-soal.

Fisika dipandang sebagai suatu proses dan sekaligus produk sehingga dalam pembelajaranya harus mempertimbangkan strategi atau metode pembelajaran yang efektif dan efisien yaitu salah satunya melalui kegiatan praktik. Hal ini dikarenakan melalui kegiatan praktik, siswa melakukan olah pikir dan olah tangan. Kegiatan praktik dalam pembelajaran fisika mempunyai peran motivasi dalam belajar, memberi kesempatan pada siswa untuk mengembangkan sejumlah ketrampilan, dan meningkatkan kualitas belajar siswa

Namun, pembelajaran praktikum di sekolah sulit dilaksanakan, terbatasnya alat dan prasarana percobaan di sekolah menjadi kendala terbesar yang dihadapi para guru. Mengatasi kendala tersebut, guru harus lebih kreatif mengupayakan praktik dengan alat- alat sederhana yaitu dengan memanfaatkan bahan atau peralatan di lingkungan sekitar.

Oleh karena itu dalam menghadapi peserta didik dengan kondisi sarana prasarana yang dimiliki, guru mata pelajaran IPA Fisika perlu menciptakan suasana kegiatan belajar- mengajar IPA Fisika yang dapat meningkatkian hasil belajar IPA Fisika khsusnya materi perpindahan kalor, dan perlu dilengkapi dengan perangkat kegiatan belajar mengajar sehingga proses pencapaian pendidikan dapat tercapai, maka penulis tertarik melakukan suatu penelitian tindakan kelas dengan judul "Meningkatkan Hasil Belajar IPA Melalui Metode Pembelajaran Pratikum Pada Materi Perpindahan Kalor Di Kelas VII SMP Negeri 1 Randangan”

\section{Kajian Teori \\ Hasil Belajar}

Menurut Gagne (dalam Slameto, 2003:13) bahwa dalam belajar dihasilkan berbagai macam tingkah laku yang berlainan, seperti pengetahuan, sikap, keterampilan, kemampuan, informasi dan nilai. Berbagai macam tingkah laku yang berlainan inilah yang disebut kapabilitas sebagai hasil belajar. Ridwan (2008: 1) mengemukakan bahwa hasil belajar merupakan hal yang tidak dapat dipisahkan dari kegiatan belajar, karena kegiatan belajar merupakan proses, sedangkan prestasi merupakan hasil dari proses belajar.

Sehubungan dengan hasil belajar, Poerwanto (dalam Ridwan, 2008: 3) juga memberikan pengertian hasil belajar yaitu "hasil yang dicapai oleh seseorang dalam usaha belajar sebagaimana yang dinyatakan dalam raport." Selanjutnya Winkel (dalam Ridwan, 2008: 3) mengatakan bahwa "hasil belajar adalah suatu bukti keberhasilan belajar atau kemampuan seseorang peserta didik dalam melakukan kegiatan belajarnya sesuai dengan bobot yang dicapainya." Sedangkan menurut Nasution (1996: 17) hasil belajar adalah: "Kesempurnaan yang dicapai seseorang dalam berfikir, merasa dan berbuat. Hasil belajar dikatakan sempurna apabila memenuhi tiga aspek yakni: kognitif, affektif dan psikomotor, sebaliknya dikatakan prestasi kurang memuaskan jika seseorang belum mampu memenuhi target dalam ketiga kriteria tersebut." 


$\begin{array}{ll}\text { Volume } & : 04 \\ \text { Nomor } & : 02 \\ \text { Bulan } & : \text { Mei } \\ \text { Tahun } & : 2018 \\ \text { http } & : / / \text { jurnal.pps.ung.ac.id/index.php/AKSARA/index }\end{array}$

Berdasarkan pengertian di atas, maka dapat dijelaskan bahwa hasil belajar merupakan tingkat kemanusiaan yang dimiliki peserta didik dalam menerima, menolak dan menilai informasi-informasi yang diperoleh dalam proses belajar mengajar. Hasil belajar seseorang sesuai dengan tingkat keberhasilan sesuatu dalam mempelajari materi pelajaran yang dinyatakan dalam bentuk nilai atau raport setiap bidang studi setelah mengalami proses belajar mengajar. Hasil belajar peserta didik dapat diketahui setelah diadakan evaluasi. Hasil dari evaluasi dapat memperlihatkan tentang tinggi atau rendahnya hasil belajar peserta didik.

\section{Metode Pembelajaran Pratikum}

Menurut Sudirman (1992:163) metode praktikum adalah cara penyajian pelajaran kepada siswa untuk melakukan percobaan dengan mengalami dan membuktikan sesuatu yang dipelajari. Hal ini didukung pula oleh Winatapura (1993:219) yang menyatakan bahwa metode praktikum adalah suatu cara penyajian yang disusun secara aktif untuk mengalami dan membuktikan sendiri tentang apa yang dipelajarinya

Melalui praktikum, peserta didik dapat memiliki banyak pengalaman, baik berupa pengamatan langsung atau bahkan melakukan percobaan sendiri dengan objek tertentu. Tidak diragukan lagi bahwa melalui pengalaman langsung (first-hand experiences), peserta didik dapat belajar lebih mudah dibandingkan dengan belajar melalui sumber sekunder, misalnya buku. Hal tersebut sangat sesuai dengan pendapat Bruner yang menyatakan bahwa anak belajar dengan pola inactive melalui perbuatan (learning by doing) akan dapat mentrasnfer ilmu pengetahuan yang dimilikinya pada berbagai situasi (Tresna Sastrawijaya, 1998 : 17). Sedangkan menurut Djajadisastra (1982, dalam Anggraini, 2012:21-22) ada tiga langkah utama yang perlu dilakukan, yaitu langkah persiapan, langkah pelaksanaan, dan tindak lanjut metode praktikum.

\section{Metode Penelitian}

Subjek penelitian ini adalah siswa kelas VII A SMP Negeri 1 Randangan yang berjumlah 27 siswa. Pelaksanaan penelitian dilakukan pada semester genap tahun ajaran 2016/2017 pada pelajaran IPA materi perpindahan kalor.

Penelitian ini dilakukan dengan menggunakan prosedur penelitian tindakan kelas (PTK). Prosedur penelitian ini terdiri dari dua siklus, dimana tiap siklus dilaksanakan sesuai dengan perubahan yang ingin dicapai. Dalam PTK ini, peneliti mengadopsi model yang dikembangkan oleh Suharsimi Arikunto.

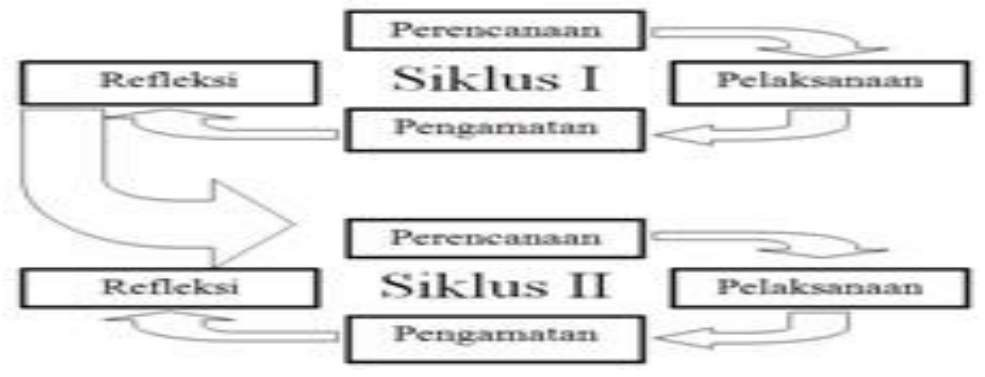




$\begin{array}{ll}\text { Volume } & : 04 \\ \text { Nomor } & : 02 \\ \text { Bulan } & : \text { Mei } \\ \text { Tahun } & : 2018 \\ \text { http } & : / / \text { jurnal.pps.ung.ac.id/index.php/AKSARA/index }\end{array}$

Secara garis besar terdapat empat tahap kegiatan yang lazim dilalui, yaitu perencanaan, pelaksanaan, pengamatan dan refleksi (Arikunto, Suhardjono dan Supardi, 2014: 16). Siklus prosedur penelitian ini dapat divisualisasikan seperti Bagan 1

Berdasarkan gambar di atas dapat dijabarkan sebagai berikut:

\section{Perencanaan}

Kegiatan yang dilakukan dalam tahap ini adalah merencanakan segala sesuatu yang berhubungan dengan pembelajaran praktikum dengan memanfaatkan alat dan bahan di lingkungan sekitar antara lain:

a. Membuata rancangan pembelajaran yang akan digunakan

b. Membuat petunjuk praktikum

c. Menyiapkan alat dan bahan

d. Membuat lembar pre tes dan lembar ulangan

e. Membuat lembar observasi untuk mengamati aktivitas siswa dalam melaksanakan kegiatan praktukum

f. Membuat angket untuk mengetahui respon siswa terhadap pembelajaran praktikum.

\section{Pelaksanaan Tindakan}

Kegiatan pada tahap ini adalah Guru memberikan pre test pada siswa, kemudian sebelum praktikum dimulai guru melakukan demonstrasi di depan kelas untuk memudahkan siswa dalam praktikum. Praktikum dilakukan di ruang kelas. Melaksanakan praktikum sesuai dengan yang direncanakan yaitu pembelajaran praktikum sesuai dengan yang direncanakan dalam proses pembelajaran.

\section{Pengamatan}

Pada tahap ini kegiatan yang dilakukan adalah mengamati segala peristiwa yang terjadi selama pelaksanaan tindakan yaitu mengamati siswa pada kegiatan praktikum.

4. Refleksi

Semua data yang diperoleh selama pelaksanaan tindakan dan proses observasi dikumpulkan dan dianalisis untuk mengkaji tujuan sementara. Hasil analisis tersebut digunaka oleh peneliti untuk merefleksi diri. Selanjutnya, hasil refleksi ini dijadikan sebagai acuan untuk merncanakan tindakan pada siklus selanjutnya. Begitu seterusnya tahap- tahap tersebut dilaksanakan bersiklua dengan materi yang berbeda sampai hasil belajar siswa meningkat.

Untuk pengumpulan data dalam penelitian ini digunakan 3 macam metode yaitu tes, observasi, dan angket. Analisis yang digunakan secara umum terdiri dari proses analisis untuk menghitung presentasi keaktifan siswa dan mengetahui tingkat hasil belajar siswa.

a) Aktivitas Siswa

Data ini untuk mengetahui seberapa besar aktivitas siswa dalam mengikuti proses pembelajaran maka dilakukan analisis pada instrumen lembar observasi dengan menggunakan teknik deskriptif melalui presentase. Adapun perhitungan prosentase keaktifan siswa adalah sebagai berikut:

Prosentase $=\frac{n}{N} \times 100 \%$ 


$\begin{array}{ll}\text { Volume } & : 04 \\ \text { Nomor } & : 02 \\ \text { Bulan } & : \text { Mei } \\ \text { Tahun } & : 2018 \\ \text { http } & : / / \text { jurnal.pps.ung.ac.id/index.php/AKSARA/index }\end{array}$

Keterangan:

$\mathrm{n}=$ Banyaknya siswa yang melakukan aktivitas sesuai indikator

$\mathrm{N}=$ Jumlah seluruh skor

$\%=$ Tingkat prosentase keaktifan siswa

Kriteria penafsiran variabel penelitian ini ditentukan sebagai berikut:

$\checkmark$ Apabila aktivitas siswa $>75 \%$ maka keaktifan siswa tinggi

$\checkmark$ Apabila aktivitas siswa 65\%-75\% maka keaktifan siswa sedang

$\checkmark$ Apabila aktivitas siswa $<65$ maka keaktifan siswa kurang

b) Hasil Belajar Siswa

Analisis tes hasil belajar siswa bertujuan untuk mengetahui tingkat keberhasilan belajar siswa yang diperoleh dari tiap siklus. Penguasaan materi pelajaran dapat dilihat dari nilai yang diperoleh siswa untuk setiap siklus.

Indikator keberhasilan yang ditetapkan dalam penelitian ini adalah: Peningkatan hasil belajar. Untuk tercapainya ketuntasan belajar klasikal yaitu $75 \%$ siswa mendapat nilai 60 atau lebih

\section{Hasil Penelitian}

Hasil pengamatan aktivitas siswa pada siklus I dapat dilihat dalam tabel berikut ini :

Tabel 4.1

Keaktifan Siswa

\begin{tabular}{|c|l|c|}
\hline No & \multicolumn{1}{|c|}{ Aktiftas Siswa } & Prosentase \\
\hline 1 & Mengajukan Pertanyaan & 71,60 \\
\hline 2 & Menjawab Pertanyaan & 72,84 \\
\hline 3 & Pengamatan & 71,60 \\
\hline 4 & Pratikum & 71,60 \\
\hline 5 & Identifikasi & 72,84 \\
\hline 6 & Berdiskusi & 72,84 \\
\hline 7 & Ketepatan Mengumpulkan Tugas & 71,60 \\
\hline \multicolumn{2}{|r|}{ Rata - rata } & 72,07 \\
\hline
\end{tabular}

Keterangan :

$75 \%-100 \%=$ Baik sekali

$65 \%-74 \%=$ Baik

$45 \%-64 \%=$ Kurang

$0 \%-44 \%=$ Kurang Sekali

Sedangkan hasil belajar dapat dilihat pada table berikut ini :

Tabel 4.2

Hasil Belajar Siklus I

\begin{tabular}{|c|l|c|}
\hline No & \multicolumn{1}{|c|}{ Nama Siswa } & Hasil Belajar \\
\hline 1 & Aditya Djafar & 70 \\
\hline 2 & Aprizal Abdul Latif & 60 \\
\hline 3 & Arfat Minggus & 60 \\
\hline
\end{tabular}




\begin{tabular}{|c|l|c|}
\hline 4 & Aswad Ruhban & 50 \\
\hline 5 & Faisal Mohamad & 80 \\
\hline 6 & Hasan Kalaha & 80 \\
\hline 7 & Husrin Mahabu & 60 \\
\hline 8 & Ikram Hasripin & 50 \\
\hline 9 & Ishak Nento & 70 \\
\hline 10 & Jusman & 60 \\
\hline 11 & Pendris Tawaa & 70 \\
\hline 12 & Rafliyanto Walangadi & 60 \\
\hline 13 & Ramdan Nihe & 70 \\
\hline 14 & Hapni Makale & 60 \\
\hline 15 & Riski Nento & 70 \\
\hline 16 & Ayun Yonu & 60 \\
\hline 17 & Cindri Makuta & 50 \\
\hline 18 & Dina Hulopi & 80 \\
\hline 19 & Fatima Uzzahra & 70 \\
\hline 20 & Hasmiyanti Nurain Hanggu & 60 \\
\hline 21 & Meilan Ripansa & 50 \\
\hline 22 & Melisa Yusuf & 60 \\
\hline 23 & Mita Pakaya & 70 \\
\hline 24 & Noviyanti Kasim & 60 \\
\hline 25 & Nurlaila Putri Abdjul & 70 \\
\hline 26 & Putri Patrisia Pouli & 60 \\
\hline 27 & Selvin Harun & 70 \\
\hline Rata - rata & 64.07 \\
\hline & & \\
\hline
\end{tabular}

Keterangan :

$$
\begin{aligned}
75 \%-100 \% & =\text { Baik sekali } \\
65 \%-74 \% & =\text { Baik } \\
45 \%-64 \% & =\text { Kurang } \\
0 \%-44 \% & =\text { Kurang Sekali }
\end{aligned}
$$

Dari tabel keaktifan siswa dan hasil belajar siswa pada siklus I tersebut dapat diketahui bahwa keaktifan siswa mencapai $72,07 \%$ da hasil belajar siswa ditinjau dari hasil belajar siklus I 64,07\%. Berarti pelaksanaan pembelajaran pada siklus I dapat dilaksanakan dengan baik tapi belum mencapai hasil yang maksimal karena sering terjadi kesalahfahaman. Hal ini terjadi karena pada siklus I kerjasama atau interaksi siswa kurang, siswa banyak yang bermain- main sendiri pada saat praktikum, siswa banyak yang tidak berani bertanya pada guru, dan siswa kurang memahami petunjuk praktikum dengan benar

Sedangkan hasil pengamatan aktivitas siswa dapat dilihat dalam tabel dibawah ini

Tabel 4.3

Keaktifan Siswa Siklus II

\begin{tabular}{|c|l|c|}
\hline No & Aktiftas Siswa & Prosentase \\
\hline 1 & Mengajukan Pertanyaan & 73,01 \\
\hline
\end{tabular}




\begin{tabular}{|l|l|c|}
\hline 2 & Menjawab Pertanyaan & 76,19 \\
\hline 3 & Pengamatan & 85,71 \\
\hline 4 & Pratikum & 76,19 \\
\hline 5 & Identifikasi & 85,71 \\
\hline 6 & Berdiskusi & 85,71 \\
\hline 7 & Ketepatan Mengumpulkan Tugas & 85,71 \\
\hline \multicolumn{2}{|r|}{ Rata - rata } & 81,17 \\
\hline
\end{tabular}

Keterangan :

$$
\begin{aligned}
75 \%-100 \% & =\text { Baik sekali } \\
65 \%-74 \% & =\text { Baik } \\
45 \%-64 \% & =\text { Kurang } \\
0 \%-44 \% & =\text { Kurang Sekali }
\end{aligned}
$$

Sedangkan hasil belajar dapat dilihat pada table berikut ini

Tabel 4.4

Hasil Belajar Siklus II

\begin{tabular}{|c|l|c|}
\hline No & \multicolumn{1}{|c|}{ Nama Siswa } & Hasil Belajar \\
\hline 1 & Aditya Djafar & 80 \\
\hline 2 & Aprizal Abdul Latif & 70 \\
\hline 3 & Arfat Minggus & 80 \\
\hline 4 & Aswad Ruhban & 70 \\
\hline 5 & Faisal Mohamad & 90 \\
\hline 6 & Hasan Kalaha & 90 \\
\hline 7 & Husrin Mahabu & 80 \\
\hline 8 & Ikram Hasripin & 70 \\
\hline 9 & Ishak Nento & 80 \\
\hline 10 & Jusman & 70 \\
\hline 11 & Pendris Tawaa & 80 \\
\hline 12 & Rafliyanto Walangadi & 80 \\
\hline 13 & Ramdan Nihe & 80 \\
\hline 14 & Hapni Makale & 70 \\
\hline 15 & Riski Nento & 80 \\
\hline 16 & Ayun Yonu & 70 \\
\hline 17 & Cindri Makuta & 70 \\
\hline 18 & Dina Hulopi & 90 \\
\hline 19 & Fatima Uzzahra & 80 \\
\hline 20 & Hasmiyanti Nurain Hanggu & 70 \\
\hline 21 & Meilan Ripansa & 70 \\
\hline 22 & Melisa Yusuf & 80 \\
\hline 23 & Mita Pakaya & 70 \\
\hline 24 & Noviyanti Kasim & 80 \\
\hline 25 & Nurlaila Putri Abdjul & 80 \\
\hline 26 & Putri Patrisia Pouli & 80 \\
\hline 27 & Selvin Harun & \\
\hline & & 80 \\
\hline
\end{tabular}


Keterangan :

$$
\begin{aligned}
75 \%-100 \% & =\text { Baik sekali } \\
65 \%-74 \% & =\text { Baik } \\
45 \%-64 \% & =\text { Kurang } \\
0 \%-44 \% & =\text { Kurang Sekali }
\end{aligned}
$$

Dari tabel keaktifan siswa dan hasil belajar siswa pada siklus II tersebut dapat diketahui bahwa keaktifan siswa mencapai $83,95 \%$ da hasil belajar siswa ditinjau dari ulangan harian $77,03 \%$. Berarti pelaksanaan pembelajaran pada siklus II dapat mengalami peningkatan yang signifikasn. Terjadi peningkatan ini dikarenakan siswa lebih aktif dalam melakukan kegiatan praktikum, tiap kelompok sudah dapat bekerjasama dengan temannya, dapat memanfaatkan waktu dengan tepat, dan siswa sudah aktif bertanya pada guru, dan tiap akhir pembelajaran guru selalu memotivsi siswa untuk belajar dan tidak takut mencoba hal- hal baru dalam belajar

\section{Pembahasan}

Berdasarkan pengamatan pada siklus I dan II dalam tabel berikut ini :

Tabel 4.5

\section{Pengamatan Siklus I dan Siklus II}

\begin{tabular}{|l|c|c|}
\hline & Siklus I & Siklus II \\
\hline Aktivitas Siswa & 72,07 & 83,95 \\
\hline Hasil Belajar Siswa & 64,07 & 77,03 \\
\hline
\end{tabular}

Keterangan :

$$
\begin{aligned}
75 \%-100 \% & =\text { Baik sekali } \\
65 \%-74 \% & =\text { Baik } \\
45 \%-64 \% & =\text { Kurang } \\
0 \%-44 \% & =\text { Kurang Sekali }
\end{aligned}
$$

Berdasarkan data dari siklus I dan II dapat dikatakan bahwa pembelajaran metode praktikum dapat meningkatkan keaktifan dan hasil belajar IPA Fisika khususnya materi perpindahan kalor. Terbukti pada siklus I keaktifan siswa mencapai $72,07 \%$ dan hasil belajar mencapai 64,07\%. Dengan perbaikan pembelajaran pada siklus II keaktifan siswa meningkat menjadi 83,95\% dan hasil belajar mengalami peningkatan menjadi $77,03 \%$. Terbukti bahwa dengan metode praktikum IPA maka kwalitas pelaksanaan pembelajaran naik. Dari hasil tersebut dapat disimpulkan bahwa benar menurut Sutarno dkk., (2007: 8.5) yang menyatakan tugas guru dalam mengajar antara lain membantu transfer belajar pada siswa.

Keaktifan siswa meningkat dari hasil siklus I ke siklus II, hal tersebut wajar karena setelah diperbaiki pada siklus I sudah ada perbaikan yang berkaitan namun karena sering terjadi kesalapahaman antar anggota kelompok, maka keaktifan siswa dalam pembelajaran IPA dengan metode pembelajaran praktikum ini masih 


$\begin{array}{ll}\text { Volume } & : 04 \\ \text { Nomor } & : 02 \\ \text { Bulan } & : \text { Mei } \\ \text { Tahun } & : 2018 \\ \text { http } & : \text { //ejurnal.pps.ung.ac.id/index.php/AKSARA/index }\end{array}$

mencapai $72,07 \%$ Seiring bertambahnya pengalaman menumbuhkan kepercayaan diri pada siswa dan keberanian. Oleh sebab itu keaktifan siswa semakin baik sehingga pada siklus II mencapai 83,95\%.

Dari hasil tersebut dapat disimpulkan bahwa benar menurut (William C. Carin, dalam Samsudin 2006: 1.7) yang menyatakann benar bahwa belajar tidak berpusat pada guru, tetapi anak harus lebih aktif. Dengan demikian terbukti bahwa keaktifan siswa dalam pembelajaran setelah penelitian semakin naik.

Sedangkan hasil belajar dengan metode praktikum juga mengalami peningkatan pada siklus I ke siklus II. Hal ini disebabkan karena seiring bertambahnya pengetahuan guru dan siswa dalam proses pembelajaran IPA khusunya materi perpindahan kalor dalam metode pembelajaran praktikum. Siswa semakin percaya diri, semakin berani berargumentasi, sementara guru semakin mapan memberikan pengarahan dan penjelasan kepada siswa. Dengan demikian proses pembelajaran semakin baik dan dapat menghasilkan hasil belajar yang semakin baik pula.

\section{Kesimpulan}

Berdasarakan hasil penelitian yang dilaksanakan melalui penelitian tindakan kelas melalui penerapan metode pembelajaran praktikum pada siswa kelas VII A SMP Negeri 1 Randangan pada siklus I dan II dapat disimpulkan bahwa melalui metode pembelajaran praktikum hasil belajar siswa pada kelas VII A SMP Negeri 1 Randangan dapat meningkat Hal ini dapat dilihat dari keaktifan siswa pada siklus I mencapai $72,07 \%$ dan pada siklus II 83,95\%. Sedangkan hasil belajar pada siklus I 64,07\% dan pada siklus II meningkat menjadi 77,03\%.Peningkatan ini dapat terjadi karena adanya perbaikan dalam setiap pembelajaran.

\section{DAFTAR PUSTAKA}

Arikunto, Suharsini. 2006. Prosedur Penelitian Suatu Pendekatan Praktek. Jakarta: Rineka Cipta.

Darsono, Max. 2001. Belajar dan pembelajaran. Semarang: IKIP Semarang Press.

Dimyati dan Muldjiono. 2006. Belajar dan Pembelajaran. Jakarta: PT Rineka Cipta.

Djamarah, Syaiful dan Aswan Zaini. 2006. Erlangga Strategi Belajar-mengajar. Jakarta: Asdi Mahasatya.

Kanginan, Marthen. 2007. IPA FISIKA untuk SMP Kelas VII. Jakarta: Erlangga.

Nasution S. 1986. Didaktik Azas-Azas Mengajar. Bandung: CV. Jemars

Purwadarminta. 1984. Kamus Besar Bahasa Indonesia. Jakarta: Erlangga.

Ridwan. 2008. Ketercapaian Prestasi Belajar. [Online]. Tersedia : http://ridwan202.wordpress.com/2008/05/03/ketercapaian-prestasi-belajar (20 Januari 2013)

Slameto. 2003. Belajar dan Faktor-Faktor yang Memepengaruhinya. Jakarta: Rineka Dipta

Sudjana, Nana. 2004. Penilaian Hasil Proses Belajar Mengajar. Bandung: Remaja Rosdakarya.

Sudirman. 1992. Ilmu Pendidikan. Bandung: Remaja Rosdakarya.

Syaiful Sagala. 2005. Konsep dan Makna Pembelajaran Bandung : CV. Alvabeta 


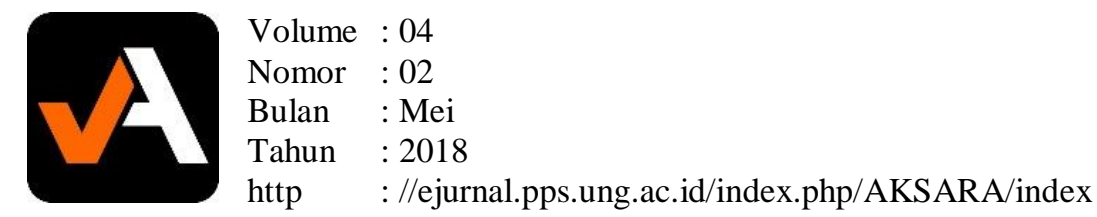

Tim MKDK.1990. Psikologi Belajar. Semarang: IKIP Semarang Press.

Tim Penyusun Kamus Pusat Pembinaan dan Pengembangan Bahasa. 2001. Kamus besar Bahasa Indonesia. Jakarta: Departemen Pendidikan dan Kebudayaan. Tresna Sastrawijaya. 2009. Pencemaran Lingkungan. Jakarta : Rineka Cipta.

Winataputra. 1993. Strategi Belajar dan Mengajar IPA. Jakarta : Universitas Terbuka Depdikbud 